\title{
CANADA GOOSE NESTING RECORD FOR BATTLEFORD
}

by Spencer G. Sealy, Department of Zoology, U.B.C., Vancouver

The Canada Goose, Branta canalensis (Linnaeus), is one of the most videly distributed and the most genrally known of our wild geese; in act, according to Godfrey (1966) it s "the wild goose to most Canadians", reeding from western Alaska eastvard to Labrador and Newfoundland and south to northeastern California, Utah, Kansas, and rarely to Maine and Massachusetts. There are many hesting records of this species for askatchewan, particularly the southrn portion of the province; however, o my knowledge none has been ecorded nesting in the Battleford area. In areas near the Battleford rea the Canada Goose has been reorded nesting at Carlton (Blakiston n Houston and Street, 1959), Kinlersley (G. A. Fox, pers. corres., 1958) and Waterhen Marsh near Kinistino (Houston and Street, 1959; McKim, 1951). Mr. C. F. Shirley (in Godfrey, 1950) stated that Canada Geese are regular spring and autumn migrants in the Flotten Lake region, but he had no evidence of breeding.

A letter addressed to Dr. Ralph D. Bird (then of Brandon, Manitoba) lated January 8, 1940, from Mr. R. Morris Ferrie of North Battleford, Saskatchewan, was recently found within the pages of a book donated to the Manitoba Museum of Man and Nature by Dr. Bird. This letter contained three photographs, two of which were of a Canada Goose nest in a tree near Battleford. Referring to two of the photographs, Mr. Ferrie wrote "One, you will note, is just a large nest in a tree; another is the same nest with a large bird leaving it. Both were taken within a few minutes. The bird leaving the nest is the female Canada Goose" (see photograph). Upon recent query, Mr. Ferrie (Secretary - Manager, Saskatchewan Fish and Game League), stated: "It is a long time since the goose nest in the tree.... As I recall it was 25 feet up

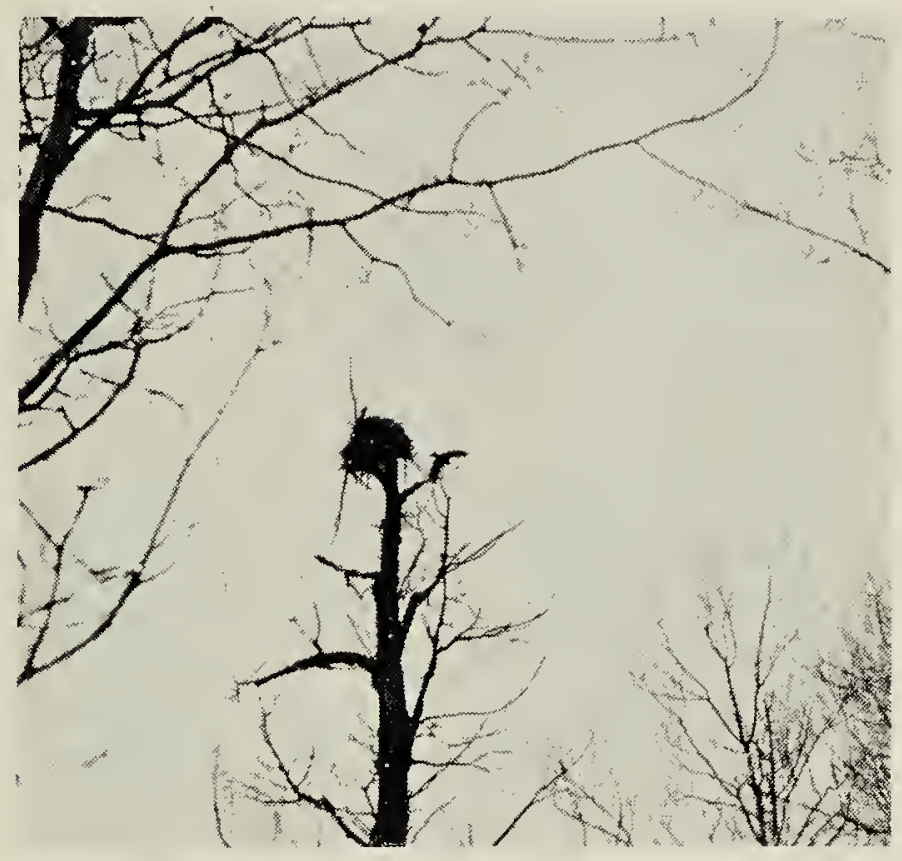

Photo by R. M. Ferrie

Canada Goose leaving nest in

Battleford area, around 1939.

or so in a black poplar tree along the North Saskatchewan River. By tapping on the tree trunk the bird was disturbed enough to get the picture of her leaving the nest" (pers. corres., R. W. Nero, April 17, 1967).

It has often been remarked that the Canada Goose shows a definite preference for islands when choosing a nest site. It commonly places its nest on the ground, in which case the island site has obvious advantages. Visibility at the nest site and its importance as a major factor in selecting nest sites has been stressed by many observers.

Although the Canada Goose commonly nests on the ground, it has often been recorded using abandoned tree nests (Bent, 1925; Godfrey, 1966; Salt and Wilk, 1958; and others), and it appears obvious that maximum visibility and freedom from mammalian predators would be afforded by placing the nest in a tree, especially in an area with dense vegetation such as exists along the North Saskatchewan River near Battleford. Klopman (1958) found at Dog Lake, Manitoba, that Canada Geese did not build ground nests in dense stands of 
vegetation and no nests were found within 100 yards of forest cover. Geis (1956), however, found that 25 percent of all island nests in Flathead Lake, Montana, were located in woods or under thick shrub cover. Since this species arrives back in the Battleford area early in the spring (April 1 in 1960 and 1961) the choice of a tree nest may have been due to the presence of snow cover; however, phenological data for 1939 (the presumed year of this nest) is unfortunately lacking.

I should like to thank Dr. Ralph D. Bird (now of Gange, British Columbia) for permitting this record to be published and Dr. Rabert W. Nero for bringing this material to my attention.

\section{LITERATURE CITED}

Bent, A. C. 1925. Life histories of North American wild fowl. U.S. Nat. Mus. Bull., 130.

Geis, M. B. 1956. Productivity of Canada geese in the Flathead Valley, Montana. J. Wildl. Mgmt., $20: 409-419$.

Godfrey, W. E. 1950. Birds of the Cypress Hills and Flotten Lake regions, Saskatchewan. Nat. Mus. Canada, Bull. 120.

. 1966. The birds of Canada. Nat. Mus. Canada, Bull. 203.

Houston, C. S., and M. G. Street. 1959. The birds of the Saskatchewan River from Carlton to Cumberland. Sask. Nat. Hist. Soc. Spec. Publ. No. 2.

Klopman, R. B. 1958. The nesting of the Canada goose at Dog Lake, Manitoba. Wilson Bull., $70: 168-183$.

McKim, L. T. 1951. Gull colony at Waterhen Marsh. Blue Jay $9(3): 4$.

Salt, W. R., and A. L. Wilk. 1958. The birds of Alberta. Queen's Printer, Edmonton.

\section{BIRDS AT INGLEWOOD BIRD SANCTUARY, CALGARY}

Some of our readers, especially those in southern Alberta, will be interested in a check-list that has just appeared of Birds recorded at Inglewood Bird Sanctuary, Calgary (February 25,1967$)$. This six-page mimeographed bulletin presents a list compiled by Cleve Wershler from the observations of members of the Calgary Bird Club. It records 135 species observed at the Inglewood Bird Sanctuary or on the river close-by since 1956. Species which occur typically in each season are indicated, and an accompanying table lists the 135 species and shows their occurrence month by month.

Visitors coming to the sanctuary to watch birds are urged to come during the peak migrations in May or August, for 65 of the 135 species recorded have been observed only during migration. These species include a number which breed in the boreal forest and Arctic tundra and stop on their flight over the prairies to feed at the few "oases" of suitable habitat that they can find, such as the Inglewood Bird Sanctuary.

One species now found at Inglewood is of special interest. Ten years ago the White-breasted Nuthatch was hardly known at Calgary; now it is seen regularly.

$\mathrm{Mr}$. Wershler emphasizes that the information given in the table is not complete, and asks for additional records. These additions should be sent to him in care of Dr. M. T. Myres, President of the Calgary Bird Club, from whom copies of the bulletin can be obtained. Write

$$
\begin{aligned}
& \text { Dr. M. T. Myres, } \\
& \text { Department of Biology, } \\
& \text { University of Calgary, } \\
& \text { Calgary, Alberta. }
\end{aligned}
$$

\section{PRAIRIE NEST RECORDS SCHEME}

All contributors to the Prairie Nest Records Scheme are asked to note that the new chairman of the scheme is Dr. Robert W. Nero of the Manitoba Museum of Man and Nature. Please write to him for nest record cards, and send your completed cards to him at the end of the season.

Cards are wanted from as many observers as are able to keep good records of individual nests or colonies of nests. If you need further advice about keeping records, please write to Dr. Nero at the following address.

Dr. R. W. Nero

Museum of Man and Nature

Winnipeg 2, Manitoba 